\title{
Food Safety and Sustainable Development
}

\section{Bezpieczeństwo żywnościowe w zrównoważonym rozwoju}

\author{
Piotr Krajewski
}

\author{
Faculty of Law and Administration, University of Warmia and Mazury in Olsztyn, \\ Warszawska 98, 10-702 Olsztyn, Poland \\ E-mail:piotr529@wp.pl
}

\begin{abstract}
Genetic engineering is most often (and apparently rightly) associated with modern agriculture and food production. But besides the real and potential advantages derived from manipulating genes of living organisms, related threats should also be noted. Food and food production provides the basis for the existence and functioning of our civilisation. Tools used by man to sustain his existence affect the environmental conditions which, in turn, determine the production capacities and availability of natural resource diversity. Therefore, human life depends on it. Their careful use will ensure development, while a lack of prudence or control over undertaken actions may have serious economic and ecological consequences.
\end{abstract}

Key words: food safety, sustainable development, GMO, genetically modified organisms

\section{Streszczenie}

Inżynieria genetyczna najczęściej (i chyba słusznie) jest kojarzona z nowoczesnym rolnictwem i produkcją żywności. Jednakże obok rzeczywistych i potencjalnych korzyści płynących z manipulowania genami organizmów żywych należy dostrzec niebezpieczeństwa z tym związane. Żywność i produkcja żywności jest bazą istnienia i funkcjonowania naszej cywilizacji. Od narzędzi jakich człowiek używa dla podtrzymania swojej egzystencji zależą warunki środowiska, które z kolei decydują o możliwościach produkcyjnych i dostępności różnorodności bogactw natury. Od tego zależy więc byt człowieka. Roztropne z nich korzystanie zapewni rozwój; natomiast brak przezorności i kontroli działań może skutkować poważnymi konsekwencjami gospodarczymi i ekologicznymi.

Słowa kluczowe: bezpieczeństwo żywnościowe, ekorozwój, GMO, organizmy genetycznie modyfikowane

\section{Introduction}

The achievements of modern biotechnologies based on genetic engineering are applied in multiple and varied ways. Since the very beginning, they have been playing a particular role in agriculture and food production. Generally, they consist in producing and processing products using living organisms or their parts. With this end in view, the genetic composition of organisms is altered using genetic engineering techniques. They are often colloquially referred to as transgenic organisms. This term indicates introduction into the DNA of a food product or an organism intended for consumption of a gene that originally does not make a part of the gene sequence. New information introduced in this way forces production and, afterwards, the expression of one or many new proteins.

The development and application of genetic engineering techniques has led to the introduction of certain traits into many species of agriculturally important plants, which is manifested, for example, in resistance to disease or changes in nutritive value. Therefore, the possibilities offered by modern biotechnology can improve the quality of human life. Those expectations provide equal justification for similar applications in medical, chemical and pharmaceutical industries. Obviously, this involves various concerns. The most important of them are connected with the application of bioengineering methods in agriculture and food production in view of the divergence of opinions concerning their possible benefits and related threats. 
Arguments for creating food based on modern biotechnologies often provided by its advocates include:

- increasing the availability of food products for developing countries;

- improvement in quality, durability and nutritive values;

- lack of residues from chemical plant protection products;

- production increase, economic effectiveness and, consequently, market competitiveness;

- reduction of deforestation and erosion of agricultural areas;

- protection of biodiversity by the creation of new cultivars;

- application in land reclamation and waste utilization processes.

On the other hand, objections that are raised against them mainly concern ethical and ecological issues. Namely, it is pointed out that:

- it is unethical to expose the man and human life environment to possible risks that science is not able to predict or prevent;

- the introduction of animal genes into plant organisms (and vice versa) can be difficult to accept;

- the cause can never justify the means; in this case, the perspective of economic benefit cannot prevail over the obligation to protect the human being, care for agriculture or the resources of own territory;

- extending intellectual property rights to genetically modified organisms reduces access to the biological potential of food production for populations of the lowest economic and scientific status;

- they demonstrate new toxic and allergenic properties;

- they will cause the emergence of new viruses and antibiotic-resistant diseases;

- we are already dealing with the first cases of biopiracy towards developing states, caused by a race to patent genetic resources;

- a significant decrease in biodiversity, both agriculturally used and natural, has already been observed;

- the use of chemical plant protection products on genetically modified crops is increasing;

- the first insects and diseases resistant to pesticides have already been observed;

- genetically modified plants can turn out to be troublesome weeds, and microorganisms can be pathogenic factors;

- they can cause serious disturbances in ecosystems.

This should be also supplemented with the genetic contamination risk, involving the introduction of new microorganisms to the environment which, by moving, reproducing and adapting to altered living conditions will be able to transfer their own traits to other organisms. Of course, controlling or reversing genetic mutation processes after their introduction to the environment is not possible by any means. Moreover, the genes of bacteria, viruses or insects which determine the synthesis of proteins which originally did not make up a part of the human diet can bring about consequences related to their introduction that cannot be predicted today. Therefore, it is not possible to ensure food safety, since products may contain substances that are toxic for human health.

As can be easily noted, a discussion concerning modern biotechnology and GMO-based agriculture development leads to a polarisation of opinions which, nevertheless, does not resolve food safety issues. Consequently, all discussions that aim to provide an answer to the questions concerning transgenic food, beside developing and improving the agricultural and food industries in the context of economic ethics, should help to identify morally accepted boundaries for scientific research and the development of technology.

\section{GMO, biotechnologies and transgenic food - ad-} vantages and threats

In the agricultural sector, the need to improve cultivars, food quality and production level are the factors with the strongest impact on the progress and development of genetic engineering methods. Therefore, research is gradually headed towards selecting specific breeds of animals, or plant cultivars in order to improve them by adding one or more supplementary features occurring in another, yet related, organism.

Today, genetic engineering already makes it possible to introduce into the DNA of an economically interesting specimen of a gene (genes) determining a new trait, which in natural conditions would never have a chance to occur in this configuration. The progress in genetic engineering is so significant that nowadays we refer to genetically modified plants as the first and the second generation. The first group includes mainly plants with those improvements which are meant to improve crop results, e.g. improvement of resistance to pests or tolerance of herbicides. They mainly include basic crop plants. The second generation plants, more diversified as regards the number of species and traits transferred by the exogene, are artificially improved towards organoleptic and nutritive features, and elimination of the negative impact of agriculture on the environment. Thus, plants with an increased number of vitamins, proteins and unsaturated fats have been created as well as those producing vaccines or artificial polymers that do not exist in nature. The aim of those activities is thus to create a genetically-modified organism demonstrating specific properties. This may involve, for exam- 
ple, quality, productivity, resistance to pathogens or unfavourable environmental conditions, thus the features which make them particularly important for the economy. Other specific properties include lower levels of contamination with residues of chemical crop protection products in food and in the environment, or the possibility to remove genes determining the production of allergenic compounds from products intended for consumption purposes and the other way round - for example, the introduction of those that lead to the production of proteins stimulating immunological reactions.

Numerous benefits of GMO can be expected in the field of environmental protection. Those mainly include plants that do not require the application of agricultural chemicals, plantations of trees that do not produce flowers and, consequently, do not interfere with natural biodiversity, or remove elements from soil such as lead or chromium. These examples are to prove that enriching plants with new properties is a delicate, predictable and controllable activity.

A precautionary approach to GMO takes into account mainly the limited predictability of trait expression. The transfer of an alien gene to a sexually incompatible organism is an element of risk in itself, as there are a lot of possibilities for unexpected genetic modifications to emerge. Therefore, it is a phenomenon which would never occur under natural conditions in which male and female gametes join together. Resistance towards genetically modified organisms usually results from threats to humankind, environment or biodiversity that are related to this technology. They include, for example, the possible emergence of toxic or allergenic substances, resistance to antibiotics, transfer of traits to microorganisms and from those microorganisms to humans, reduction of natural and useful biodiversity, the spread of exogens with pollen ${ }^{1}$ and, in the case of sudden complications - the risk of agricultural collapse. Moreover, the possibility of side-effects emerging in the long-term future that obviously cannot be specified today, cannot be omitted.

The transfer from the cultivation of genetically-modified plants to food products obtained from them is relatively simple. The possibilities offered by GM crops are, as is known, abundant: fruit that does not spoil, cereals with an increased content of iron and vitamins or beets with a high sugar content. However, a common feature of all these plants is the inclusion of foreign genes and the production of foreign proteins as a result of exceeding natural boundaries separating one species from others. In most cases, the introduced alterations mainly concern two traits, namely, resistance to increased doses of herbicides and the production of endotoxins protecting them against harmful insects. Three transgenic species are prevalent in Europe. These include: soya

\footnotetext{
${ }^{1}$ This concerns mainly the so-called gene flow, an exogen transferred to other plants together with the male gamete in the pollination process.
}

bean resistant to increased doses of chemical pesticides, maize which is toxic for attacking insects and insecticide-resistant rapeseed. These are also the most widely-cultivated plants in the world. Do they pose a threat to global food production?

To date, we do not have adequate knowledge to predict the risks resulting from releasing GM plants to the environment and from using transgenic food. The interactions of various types between the transgene and the DNA into which it has been inserted are unknown and they remain uncontrollable. What is equally difficult to predict is the impact of plants subject to modifications on other organisms that are economically neutral or even harmful but which coexist with humans.

Genetic engineering in agriculture is also perceived as a solution for an ecological crisis caused by the industrialisation of agricultural and food production. Those benefits are to result from the limited use of chemical crop protection products, improvement of food storage and preservation technologies and increasing yields from areas with a low soil fertility, assuming that this will not involve the occurrence of unpredictable side effects.

The scientific, political and economic debate around the GMO is particularly heated. The reason for this is also unusual, since both supporters and opponents motivate their position not only with scientific and technical arguments, but also with ethical ones. Of course, those do not go into the subject matter scope of possible medical or economic benefits of using genetically modified organisms, but they directly touch on philosophical and ethical principles, which include, for instance, the freedom of research and boundaries which it should encompass.

Therefore, it would seem that in many cases the cultivation of GM plants brings many advantages (and will bring more of them in future) and that it will make it possible to attain unusual results in pharmacology, preventive medicine and, above all, in the agri-food industry due to (apparently justified) hopes for improving the food produced. Nevertheless, the introduction of GMO products to markets has revealed a series of problems related to allergies as protective reactions of the body to unknown proteins included in consumed products or in the surrounding environment, e.g. through contact with pollen of transgenic plants. This should be also supplemented with serious doubts related to economic and social repercussions in the labour market, resulting mainly from the fact that the concentration of potential and scientific knowledge in this field still belongs only to a handful of transnational biotech corporations. No wonder that their actions - actually profit-oriented - focus on restricting the contractual freedom of other business entities and on controlling the directions of agricultural development. 
To take into account all observed problems concerning food production, what is needed first of all is time, which we are gradually becoming short of. How to reconcile ecological, sanitary, economic and ethical requirements and expectations in legal regulations, which are necessary to guide scientific and economic activities of the biotechnological farming and food processing industries, and in such a way so that they satisfy the basic paradigm - innovative and conscious sustainable development? The assumption is that it will avoid or minimise serious and irreversible changes to the environment, upset the delicate balance of ecosystems and threaten human, plant and animal life.

\section{Legal regulations and principles concerning food safety}

Recent years have seen a significant sensitization of European consumers, who are increasingly turning to typical products of specific quality, which may be considered as an expression of changes in food safety perception. Possibly, this is an effect of the gradually growing awareness of citizens, aroused by wide-spread knowledge and reinforced by cases in the media concerning threats of a sanitary-epidemiological nature ${ }^{2}$. Those events undoubtedly marked their impact on the agricultural and food processing sector and on changes in culinary habits. However, a greater effect on consumer attitudes oriented towards improvement of the food quality and its impact on human health should be attributed to attitudes resulting from the economic outcomes of business and social development. From this viewpoint, the exceptional role of the agri-food sector in ensuring expected requirements and improving life quality becomes obvious. It is chiefly related to food safety, commonly regarded as an absolute priority, and to protection of the natural environment combined with its reasonable or sustainable use.

At this assumption, the use of genetically-modified organisms overlaps the problems of reconciling consumer expectations with what agriculture is able to offer by allowing transgenic crops. The discrepancy of the opinions on this topic results from the variety of information and published data. Scepticism, and even resistance, towards GM products is caused by doubts as to their quality. This is the result of the lack of scientific and moral conviction of their harmlessness (or at least neutrality) for human health and for the environment. Objections are also raised regarding control systems aimed at ensuring the quality and safety of marketed products.

\footnotetext{
${ }^{2}$ This concerns, e.g. recorded cases of bovine spongiform encephalopathy (BSE), poultry and eggs contaminated with dioxins, bird and swine flu, fodder contaminated with dioxins and aflatoxin, etc.
}

Therefore, the numerous concerns related to the consumer protection are understandable, as such protection must, on the one hand, take into account the requirement of safety of the transgenic product, and on the other, take into consideration all economic, ethical, social and legal aspects. Consumer protection is not limited only to removing threats of a hygienic and sanitary or epidemiological nature. Its task is also to provide cognitive instruments making it possible to undertake conscious decisions based on information obtained in this area. According to these needs, a series of food-related regulations have been created, aimed at ensuring safety and the hygienic and sanitary quality of products intended for consumption. Those guarantees are intended to cover the entire production cycle, thus creating a closed food safety system.

Generally, western countries have already introduced provisions concerning controlled use of genetically modified organisms and their introduction into the environment. They are mostly based on the precautionary principle. The legislators refer to the need to carry out a precise risk assessment before any activities in this regard are undertaken. This concerns both initiating research activity and production, and in a particular manner, marketing.

Undoubtedly, the best-developed legislation in this regard is that of the European Union, which has introduced, for instance, a unified policy for GMO and biotechnology. Regulations concerning the contained use of genetically modified microorganisms, the release of transgenic organisms to the environment or marketing of those organisms and/or products created from, production and trade of sowing material or legal protection of biotechnological inventions should be particularly emphasized at this point. The key EU regulations include Regulation No. 178/2002/EC establishing the European Food Safety Authority. This regulation also establishes procedures for ensuring safety in this field as well as risk assessment. It provides a basis for provisions aimed at the protection of human life and health by introducing a control system enabling the monitoring of food or its components over the entire process from the producer to the consumer. This regulation constitutes a very important stage in the intervention of public institutions in the development of legislation protecting citizen health and examination of properties of food products by establishing precautionary rules to be followed in the production and functioning of the food market. On the other hand, a closer explanation of the content of precautionary/prudence principle can be found in the EU Green Paper on the General Principles of Food Law (1997) and in judicial decisions ${ }^{3}$.

\footnotetext{
${ }^{3}$ The precautionary principle, initially referring almost exclusively to issues concerning natural environment protection was introduced into the EU legislation in Art. 174.2 TEU: Union policy on the environment (...) shall be based on the precautionary principle and on the principles that
} 
A continuation and, at the same time, a subsequent stage, in the development of community food legislation was the White Paper on Food Safety (2000). The intent was to create a system of legal protection of consumer health throughout the entire production chain. This system was intended to function along with national and EU controlling institutions. With this aim in view the following resources were employed: the European Office for Food Safety, previous legislation (covering numerous issues of food safety from the field to the table), the existing national control systems, promotion of new food policy and extending cooperation with other, non-European producers.

Another important document, with a broader range than the previous ones, is the Cartagena Protocol (2000). Its scope - besides food problems - was extended to biological safety, international transport and trade in genetically-modified organisms. Its purpose is the protection of biodiversity, health of people and organisms, permanence of wild and economically-used ecosystems and protecting them against potential dangers related to those issues. This made it possible, for instance, to correlate those works with amended requirements concerning the labelling and marking of GMOs or GMO-derived products. Regulation 278/97/EC concerning novel foods and novel food ingredients and Regulation 1813/97/EC concerning the compulsory indication on the labelling of certain foodstuffs produced from genetically modified organisms have a particular significance in this regard. The maximum compatibility of the development of modern food production biotechnology along with the protection of public health and environmental safety in the European Union, besides the above-mentioned acts, is to be ensured, for example, by Regulation 1829/2003/EC on genetically modified food and feed, which establishes procedures for approving and supervising food and feed produced using GM products. The process also takes into account the environmental risk assessments carried out for the EFSA (European Food Safety Authority). The European Union has also introduced rules for labelling and monitoring GMO-derived food and feed. Regulation 1830/2003/WE concerning the traceability and labelling of genetically modified organisms and the traceability of food and feed products produced from genetically modified organisms provides the consumer with information enabling conscious decision making and avoiding misleading the consumer as to the method of manufacturing or producing a given food product. Food and feed covered by this regulation must be clearly marked as genetically modified. GM products and components should therefore be properly labelled and traceable at each production and distribution stage. The objective of

preventive action should be taken (...). Point 9 of Annex 1 indicates, e.g. that if it is not possible to make a full risk assessment, measures should be based on the precautionary principle, i.e. appropriate measures should be taken
Regulation 65/2004/EC is to establish a system for the development and assignment of unique identifiers for genetically modified organisms. In a certain sense, this is a legislative consequence of Directive 2001/18/EC on the deliberate release into the environment of genetically modified organisms, Regulation 1946/2003/EC on transboundary movement of genetically modified organisms or Regulation 49/2000/EC concerning the compulsory indication on the labelling of certain foodstuffs produced from genetically modified organisms.

As results from an analysis of those acts, procedures concerning authorization for introduction into the market and consumption of transgenic products are subject to gradual transformations aiming at improvements of authorization procedures. Also, practice shows a growing number of authorizations hedged with safety and control requirements based on the possibilities to label, trace and monitor genetically modified products introduced to the market. Moreover, decisions taken by authorities, mainly in view of the so-called novel food, show a trend/requirement for introducing elements of an ethical or philosophical nature. Today it seems natural, although it is not always obvious and not for everybody that numerous discussions of the ethics of introducing modern technologies to food production (beside their cost-effectiveness, environmental and social impact), inevitably and always lead to questions on ethically-acceptable legal solutions - of course considering related risk. Thus, a precautionary approach to the biotechnology of food production and processing seems to be justified. Obviously, one cannot deny the rightness, and even the need to develop research from which we expect so much. Maintaining a sensitive distance towards biotechnological inventions and their application on a broad scale without previous multi-directional verification of their environmental impact, should remain, for the time being, a standard. Fortunately, human health and the condition of the natural environment still prevail over tempting institutional and economic needs and interests (at least in Europe). However, what can be clearly observed is the need to impose limitations dictated by such values as human life or the protection of diversity of living nature by excluding or at least maintaining strict control over the use of genetic diversity resources. It will definitely not be enough to temporarily impose thresholds protecting against the passive experience of results. Methods to develop internal mechanisms activating an ethics of responsibility allowing for conscious co-participation of the possible largest number of persons in the decision-making processes of managing those innovations according to principles of sustainable development of own economy based on the principles of

without having to wait until the reality and seriousness of those risks become fully apparent (cf. decision of the Tribunal of Justice of 5 May 1998 in case C-157/96, National Farmers' Union et al., Rec. p. I-2211, Point 63). 
intra- and intergenerational solidarity should be sought.

Today, the fact that modern biotechnology, besides many hopes, also generates new problems, is not a new finding. These problems include, for example, the obligation to inform citizens and to take their opinion into consideration, but also multiple consumption-related formation and education tasks. This results from the ethical imperative to respect the freedom of the individual and from the collective awareness of sustainable development based on own resources, which is so much needed today.

\section{Biodiversity and environmental impact in food production}

Since the acceptance of the Convention on Biodiversity (1992), it has been an unquestionable fact that the genetic diversity of the living world in the international legal space should be treated as a unique resource at risk (Par. 20 of the Preamble to the Convention), for example, by the introduction of modern food production and processing technology. This risk concerns not only the undesirable effects of consuming products produced from, or containing, genetically modified organisms, but also the ecological context in which this food is produced. These concerns are caused by the almost total unpredictability of results of introducing genetically modified organisms to the environment. As of today, it is difficult to even talk about its positive or negative results, since new gene combinations always cause changes (not always recorded by a humans). This is an effect of the common spontaneity of reproduction processes in nature, in which the transfer of genes within the species and between unrelated specimens remains totally beyond the control of man.

Controversies around the use of genetically-modified organisms in agriculture result from concern about their harmful impact on the natural biodiversity and the balance of ecosystems. However, sustainable development is not only guided by ecological criteria and it should not entirely omit, for example, the economic impact of new food production technologies, or the advantages of a quantitative and qualitative nature. The question is whether we are able, at least approximately, to seize at least the most important nuances of this completely unprecedented ecological and economic profit-and-loss account. Of course, profits are not a problem. What should raise concern, is, first of all, the possible consequences, whose character and scope we are not able to determine. As a less revolutionary alternative (i.e. predictable and controllable), traditional methods of improving the features by crossbreeding specimens of the same, and in exceptional cases, related species are postulated. Undoubtedly, this method requires incomparably more time and is of relatively low precision. On the other hand, genetic engineering helps to significantly shorten the experimental time and easier attainment of expected results can be emphasized. But is it also true for the long-term effects of the impact of organisms obtained by this method, directly through food and indirectly through the environment, on the human being? Whether and what reactions can be expected from the ecosystems and organisms which man has so seriously changed?

Potential threats are seen in the genetic pollution of wild species, the transfer of herbicide-resistance, immunity development in pests, transgenic pollen transfer, an increase in the application of plant protection methods and a decrease of biodiversity. Significant concerns are also raised by the impossibility of the peaceful coexistence of transgenic crops with the so-called traditional and ecological crops, just for the risk of pollution, upsetting the balance and causing damage to diversity.

Of course, the argument of the probable occurrence of suggested damages cannot override the proposal of increasing food production, improving organoleptic properties and the perspective of limiting the possibility of applying farming chemistry harmful for the environment. The degree of involvement of supporters and opponents of those changes involves the world of politics, economics, science and ethics, making it impossible to reach a compromise. The concept of biodiversity is always in the centre of discussions and it should always remain and be treated as the final objective of each activity related to gene manipulation, as it is the source of uniqueness, variety and wealth of the farming sector. The process of standardization of crop species implies gradual homologation of habits and inclinations, with a simultaneous departure from the diversity of culinary and related cultural traditions. Eradicated species cannot be replaced by man in an arbitrary manner, with the omission of subtle evolutionary processes; such modus operandi inevitably must lead to the collapse of ecosystem efficiency and thus threatens stability and continuity of food production, considered in qualitative and quantitative terms.

To rectify the situation, it is worth starting with counteracting the genetic erosion of wild species and to maintain the maximum diversity of agricultural species. A modern economy should therefore be oriented towards sustainable use of the existing potential of plants and animals forming the basis of human existence, for instance, for the mere fact that they already are here, cost nothing and have turned out to be ecologically useful. On the other hand, the potential of genetically modified organisms should be considered in the context of their unusual possibilities, but only as substitutes for current food sources in case they prove inefficient and under conditions enabling full control over them (e.g. in contained systems). However, they should be comprehensively examined before that in terms of human and environmental safety.

Moreover, the precautionary principle, which in a changed reality forces a search for a new point of 
balance between real and/or possible threats caused by the presence of GMO and expected benefits resulting from it, must be remodelled. It is about the real and the maximum (and not only cultural and ethnographic) use of the potential related to traditional knowledge and local natural resources in agri-technology and the culture of a given region (Krajewski, 2013).

\section{Ethical implications of introducing novel food}

The introduction of so-called novel food to the market is related not only to transformations in the economy and the environment, but also to serious changes in the sphere of individual and collective ethics. This clearly results from the fact that nutrition entered the legal area and the right to food became, to some extent, a fundamental law. Therefore, the entire subject matter related to production of food particularly that produced with the use of modern biotechnological methods - besides technical, ecological and legal issues, automatically requires a deeper ethical analysis. The development of civilisation has resulted in food and nutrition not being perceived today as a usual manifestation of physiological processes. They have also changed their character, from individually-treated consumption, we have moved towards socially-managed processes of food and agricultural industry and controlling the distribution of its products. Therefore, the problem is not minor since it contains a significant load of existential and ethical dilemmas. Indeed, what is at stake here is the future of the human community and environment. The answer to the question of what to do somehow arises by itself. It seems rather simple and obvious, at least when dealing with theory and generalities. Implementation of specific solutions usually proves much more complicated and determined by scientific and economic pragmatism. This is mainly for the fact that genetically modified organisms and food produced on their basis are already a fact. Unquestionably, they will remain real. Science has chosen this path and it does not seem to be willing to resign from it (at least until it investigates gene manipulation possibilities). From science in the first place, and then from practice, we should therefore expect conscious rationalism, responsible for the risk, and scientific realism which is reasonable in its determinism.

At this point, important differences between research work and practical implementation of discoveries and inventions obtained through research should be emphasized. Learning the secrets of nature is the main task of science, provided that this is achieved with the use of acceptable methods and is oriented towards implementation of objectives aimed at constructing the integrity of man and improving the quality of human life.

Practical implementation of the results derived from cognitive activities requires subjecting them first of all to critical assessment from the perspective of philosophy, ethics, law, social sciences and distancing themselves from subjecting everything only to one criterion - profit. The welfare of the man and the human environment has to be an invariable point of reference for all actions that may change existence conditions. Therefore, everything depends on the scale and the method of applying scientific achievements, since from the ethical point of view, it is not right to depart from most promising discoveries without gaining better knowledge about them only for the probability of the risk they involve or immediately implement, without previous examination of their usefulness and developing safe principles for their correct application. The most important of them undoubtedly includes caring for the common good, while recognizing the logic of the market and interests of the group. Therefore, particular caution in activities is required and if there is a probability of a negative effect, a higher organisational precaution should be demonstrated. Due to the risk of weakening the productivity of the life-giving ecosystem, safety of produced food or feed, we are facing changes that may be impossible to reverse. Under these circumstances, it is the moral obligation of everybody to pose a question about the acceptability of subjecting humanity to such experiments. These doubts are serious, especially for the fact that biological phenomena (including genetic modification) cannot be assigned a linear character, as is the case in physics or chemistry, where a specific factor always causes a foreseen effect. The environment, as an open system, in principle, is unpredictable due to the dynamics of mutual relations between species and a multitude of variables affecting the final result. Under these circumstances, ethical assessment concerning the introduction of genetically modified organisms to food production also becomes important from the point of view of an ordinary consumer, since it involves the quality of products containing or consisting of GMO available on the market. Of course, they are expected to be healthy and of full value in nutritional terms. Thus, the consumer is not only the final, but also the most important, link in the entire production chain. The fact that a consumer has been provided with a series of rights and obligations is not accidental. The life or health of consumers may not be put at risk from superficial or unscrupulous regulations governing food production, processing or distribution. Specific regulations concerning quality control, issuing quality certificates or monitoring components and production from the field to the table are to serve as safeguards in this regard. Information obtained from research institutions and practitioners should be used for developing a sense of making the right decision in consumers, i.e. conscious autonomy and participation in decision-making processes. Therefore, one can talk about building a specific type of consumer ethics, taking into account a broad spectrum of interests: 
own, group, national and ecological interests. At the same time, own and group interests cannot be treated in isolation from national and ecological interests, since they mutually supplement and overlap - they are interrelated and equally important.

\section{Summary}

The issue of protecting individual and collective interests involves the formation of a framework for institutional and formal safeguards for the conservation of natural biological diversity treated as the welfare of the entire humankind (Par. 3 of the Preamble and Art. 2 of the Biodiversity Convention), while the use of transgenic organisms (particularly in agriculture) reduces rather than protects this diversity. The creation of gene banks cannot change a lot in this matter. Thus, this is not only a problem of ecology, but also (or even primarily) an ethical problem. While examining the issue, a question arises, somehow spontaneously, whether it is morally acceptable to impoverish the diversity of living organisms and to deprive oneself or others of this abundance of features and properties that they represent. Therefore, the point at issue is the well-being of man and his living environment and, only after that, welfare understood as an economic category. Food safety should be oriented towards quality-promoting activities in agriculture and environment, since interference with nature is morally justified only when it is made with respect to the peculiarity of the features of the examined and used organisms. This eco-compatibility should be the subject of unceasing care of every consumer, since it is directly related to the quality, and therefore the safety, of his/her living environment. Technological, control or scientific information flow systems should be constructed according to the aims of civilisation, without breaching the criterion of ecologic safety. For this reason, the use of privileged economic position towards states struggling with economic problems by carrying out investments harmful for their natural and agricultural environment is ethically unacceptable. In this way, we again arrive at the social dimension of environmental ethics and food safety of modern biotechnologies and agriculture.

\section{References}

1. Cartagena Protocol on Biosafety to the Convention on Biological Diversity, 2000.

2. Directive 2001/18/EC on the deliberate release into the environment of genetically modified organisms and repealing Council Directive 90/220/EEC (OJ L 106 of 17.04.2001).

3. KRAJEWSKI P., 2013, The Rights of Local Communities and Their Role in the Sustainable Exploitation of Biodiversity, in: Problemy Ekorozwoju/Problems of Sustainable Development vol. 8, no 1, p. 57-64.

4. Regulation No. 278/97/EC concerning novel foods and novel food ingredients (OJ L 433 of 14.02.1997).

5. Regulation No. 1813/97/EC concerning the compulsory indication on the labelling of certain foodstuffs produced from genetically-modified organisms of particulars other than those provided for in Directive 79/112/EEC (OJ L 257 of 20.09.1997).

6. Regulation No. 49/2000/EC amending Council Regulation (EC) No 1139 concerning the compulsory indication on the labelling of certain foodstuffs produced from genetically modified organisms of particulars other than those provided for in Directive 79/112/EEC (OJ L 006 of 11.01.2000).

7. Regulation No. $178 / 2002 / \mathrm{EC}$ of 28.01.2002 laying down the general principles and requirements of food law, establishing the European Food Safety Authority and laying down procedures in matters of food safety (OJ L 31 of 01.02.2002, p. 1, as amended).

8. Regulation No. 1829/2003/EC on genetically modified food and feed (OJ L 268 of 18.10.2003).

9. Regulation No. 1830/2003/EC concerning the traceability and labelling of genetically modified organisms and the traceability of food and feed products produced from genetically modified organisms and amending Directive 2001/18/EC (OJ L 268 of 18.10.2003).

10. Regulation No. 1946/2003/EC on transboundary movements of genetically modified organisms (OJ L 287 of 05.11.2003).

11. Regulation No 65/2004/EC establishing a system for the development and assignment of unique identifiers for genetically modified organisms (OJ L 10 of 16.01.2004).

12. UN, Convention on Biological Diversity of 5 June 1992, Rio de Janeiro, http://www.cbd. int/convention/ (1.02.2014). 